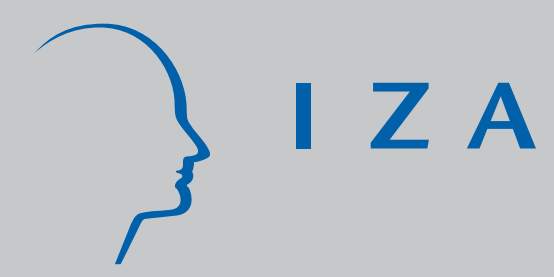

IZA DP No. 84

The Heterogeneity and Cyclical Sensitivity of Unemployment: An Exploration of German Labor Market Flows

Christoph M. Schmidt

December 1999 


\title{
The Heterogeneity and Cyclical Sensitivity of Unemployment: An Exploration of German Labor Market Flows
}

\author{
Christoph M. Schmidt \\ AWI-University of Heidelberg, IZA, Bonn and CEPR, London
}

Discussion Paper No. 84 December 1999

\author{
IZA \\ P.O. Box 7240 \\ D-53072 Bonn \\ Germany \\ Tel.: +49-228-3894-0 \\ Fax: +49-228-3894-210 \\ Email: iza@iza.org
}

This Discussion Paper is issued within the framework of IZA's research area Mobility and Flexibility of Labor Markets. Any opinions expressed here are those of the author(s) and not those of the institute. Research disseminated by IZA may include views on policy, but the institute itself takes no institutional policy positions.

The Institute for the Study of Labor (IZA) in Bonn is a local and virtual international research center and a place of communication between science, politics and business. IZA is an independent, nonprofit limited liability company (Gesellschaft mit beschränkter Haftung) supported by the Deutsche Post AG. The center is associated with the University of Bonn and offers a stimulating research environment through its research networks, research support, and visitors and doctoral programs. IZA engages in (i) original and internationally competitive research in all fields of labor economics, (ii) development of policy concepts, and (iii) dissemination of research results and concepts to the interested public. The current research program deals with (1) mobility and flexibility of labor markets, (2) internationalization of labor markets and European integration, (3) the welfare state and labor markets, (4) labor markets in transition, (5) the future of work, (6) project evaluation and (7) general labor economics.

IZA Discussion Papers often represent preliminary work and are circulated to encourage discussion. Citation of such a paper should account for its provisional character. 
IZA Discussion Paper No. 84

December 1999

\section{ABSTRACT}

\section{The Heterogeneity and Cyclical Sensitivity of Unemployment: An Exploration of German Labor Market Flows}

It is often argued that the labor market outcomes of several "problem groups" of German workers suffer disproportionately in an economic downturn. These groups are women, the unskilled, and young and old workers, respectively. Using monthly individual-level data for West Germany for the period 1983 to 1994, this paper explores both the demographic heterogeneity of German unemployment in the long term, and the cyclical sensitivity of the unemployment experience across demographic groups. The analysis moves beyond that of unemployment rates to a detailed investigation of transition rates from employment to unemployment and vice versa. While long-term differences across demographic groups are dominating the structure of both job loss and re-employment, estimation of a nonlinear regression model reveals additional aspects of cyclical sensitivity. In particular, young workers experience drastically more pronounced swings in their labor market performance than the average worker, whereas old workers seem basically isolated from the economic cycle. By contrast, in terms of its cyclical sensitivity, the labor market performance of women and of unskilled workers is not dramatically different from that of the average worker.

JEL Classification: J63, J64, J21

Keywords: Skills, transitions, unemployment duration, labor market states

Christoph M. Schmidt

University of Heidelberg

Alfred Weber Institute AWI

Grabengasse 14

D-69117 Heidelberg

Germany

Tel.: +49-6221-542955

Fax: $+49-6221-543640$

Email: Christoph.Schmidt@urz.uni-heidelberg.de

\footnotetext{
A preliminary version of the paper was given at the Annual Meeting of the European Society for Population Economics in Torino and at the CESifo Symposium on "The European Unemployment Problem" in München, both in June 1999. I am grateful to conference participants and to Boris Augurzky, David Card, Jochen Kluve, and Ralph Würthwein for their comments, and to the Center for Labor Economics, UC Berkeley, for its hospitality.
} 


\section{Background: The Unemployment Experience of "Problem Groups"}

Unemployment does not fall uniformly on workers. Instead, some workers seem to experience a higher risk of losing employment, less success in finding employment once being out of a job, and - on average - a higher unemployment rate than others. This heterogeneity across workers is quite substantial. As an illustration, for 4 three-year subperiods, 1983-85 to 1992-94, Figure 1 documents average unemployment rates of West German men and women, respectively, in 9 demographic cells distinguished by age and formal education level ${ }^{1}$.

It is apparent that the dispersion of unemployment rates across demographic groups during any period exceeds by far the fluctuation of the complete structure over time. Furthermore, the female unemployment structure seems considerably more homogeneous than that of male workers. In the largest demographic cell, workers of medium age and medium education, women experience a larger unemployment rate than men, though, pulling the average unemployment rate of female workers above that of male workers. Finally, as unemployment rates fluctuate across the economic cycle, there is a discrepancy of volatilities across demographic groups. Several demographic cells work their way up and down in the ranks as the cycle unfolds, while others retain their relative position.

This level of detail goes beyond the analytic standard in the debate on German labor market policy, however. Instead, based on relatively coarse aggregate data, observers of the German labor market, economists and the general public alike, have apparently identified several "problem groups" whose labor market prospects seem daunting, women and unskilled workers, and - implicated less frequently - young and old workers, respectively. As a consequence of their difficult position, it is often argued that it might be warranted to target labor market policy directly to these groups of workers. Moreover, one might contemplate the implementation of labor market reforms which are specifically designed to improve the employment prospects of these problem groups.

Yet, despite these potentially drastic consequences for the appropriate economic policy, little is known about either the long-term structure of unemployment or its behavior over the cycle. One principal piece of evidence justifying the particular attention being

${ }^{1}$ The figures are based on the individual-level data described in detail in section 2, and analyzed more formally in sections 3 and 4. Individual demographic cells are labeled successively as "a1e1" for the lowest age and the lowest education level, to "a3e3" for highest age and highest education level. Workers of medium age and medium education, the labor force "core", are labeled as "a2e2". 
awarded to these "problem groups" are the comparatively high unemployment rates of women and, even more pronounced, of unskilled workers. Second, the unemployment rates of unskilled workers seem to have increased dramatically in recent years (for a recent comprehensive summary of the aggregate German unemployment structure see for instance Zimmermann et al. 1999).

In such an account of the aggregate data, most German analysts would refer to workers without a formal post-secondary education as "unskilled", although skills might also arise in the form of work experience, thus inextricably linking human capital endowments and age. In a comparison across OECD countries, Germany does typically stand out for its comparatively low youth unemployment rates. This has apparently led many observers to conclude that young German workers are particularly well protected from adverse labor market shocks by the German system of post-secondary education, most prominently by the often heralded apprenticeship system. On the other hand, unemployment rates of old German workers are far from being negligible. In particular, the apparent notion that old workers who lose their jobs face low prospects of finding re-employment has fueled intense debates over the apparent benefits of early retirement schemes.

The potential of any bivariate analysis (unemployment rates by age, unemployment rates by education etc.) is necessarily limited, however, since the leading individual characteristics tend to be correlated with another. For instance, the female labor force is generally younger and less skilled than the male labor force. As another example, many young workers lack formal education, but might acquire more training as they get older. Correlations such as these make it all but impossible to characterize the demographic structure of German unemployment satisfactorily in simple bivariate terms. Thus, it will be important to provide a simultaneous account of the demographic heterogeneity of unemployment along several principal lines - as in Figure 1-, a strategy that almost inevitably requires individual-level data.

Even a thorough analysis of unemployment rates will not reveal the mechanics underlying their demographic heterogeneity, though. One has to ask, whether for any given demographic group, its unemployment rate is typically relatively high (or low), because workers in this group tend to lose their jobs more (less) often than other workers, because they have a more (less) difficult time finding re-employment, or because of both? These questions can only be addressed by an investigation of labor market flows, again at the level of detailed demographic cells. As for unemployment rates, it will be difficult to base such an 
analysis on anything less detailed than individual-level data. In addition, individuals have to be observed over time to allow a description of their movements across labor market states.

Finally, characterizing the average demographic structure of unemployment rates and of transition intensities across labor market states does hardly provide a complete account of the facts. To the contrary, it might be quite instructive to extend the analysis further to describe the behavior of the complete structure of rates and flow intensities over the cycle. For instance, a simple neo-classical model of the labor market might pose that low-skilled unemployment is caused by a wage floor set by a monopoly union, whereas the labor market for skilled workers can be treated as competitive. Consequently, adverse shifts to labor demand affecting both skilled and unskilled workers would typically not be compensated sufficiently by corresponding wage adjustments in the low-skilled market, inevitably leading to increasing unemployment of low-skilled workers.

While this or similarly designed models of the labor market apparently shape the thinking of many German economists, without looking at the data more closely it is far from obvious that the behavior of unskilled unemployment over the cycle actually displays a pattern consistent with the models' predictions. Instead, any informed discussion of these issues is in desperate need of the corresponding stylized facts. What is therefore required in order to provide a satisfactory account of the cyclical behavior of unemployment rates and flow intensities in the various demographic cells, is a formal model that is restrictive enough to condense the information, yet flexible enough to capture the demographic heterogeneity of cyclical patterns.

Using monthly data for West Germany from the German Socio-Economic Panel GSOEP for the period 1983 to 1994, this paper directly addresses these questions, (i) the permanent demographic heterogeneity of unemployment rates and of transition intensities, and (ii) the cyclical behavior of this demographic structure. The analysis is based on a detailed monthly account of worker flows between three principal labor market states, employment, unemployment, and out-of-the-labor force, and on detailed information regarding major demographic characteristics, gender, age, and education. In the course of the analysis, the paper suggests a specific empirical model that parsimoniously characterizes the long-term structure of unemployment rates and flow intensities across 18 demographic cells. In addition, the model captures cyclical behavior by a series of loading factors translating unobserved aggregate shocks to the labor market into observed fluctuations in cell-specific unemployment rates and transition intensities. 
The paper extends the analysis of Schmidt (1998) mainly in considering this formal non-linear model capturing the cyclical sensitivity of various demographic groups to overall shocks to the labor market. The second section of the paper provides a brief account of the relevant literature and a description of the data material, the third section develops the empirical model and presents the results on unemployment rates, and the fourth section analyzes flow intensities. The fifth section concludes with a summary of the results and a discussion of their implications.

\section{Literature Review and Description of the Data Base}

\section{The European Unemployment Problem in the Literature}

Two strands of the literature provide the background for this analysis. First, it is frequently argued that labor market rigidities are at the heart of the European unemployment problem (e.g. Siebert 1997). To its proponents, the principal piece of evidence supporting their view seems to be the divergent behavior of US and European unemployment during the 1990s. Since the US labor market is rarely stigmatized as being too rigid, and US unemployment has been low throughout the last decade, the conclusion that rigidities are to blame seems to suggest itself. Yet, the European unemployment experience itself has been quite heterogeneous, as has been the extent of regulatory interference with labor demand and supply.

This makes it difficult to provide a reasonable account of the issue just by eyeballing the data, even when one's thinking is guided by simple and logically consistent theoretical

models. Similarly, given the relatively moderate within-country variation in regulatory experience and in labor market outcomes over time (see again Figure 1), time series analysis for a single country (as in Berger 1998) will hardly be able to provide a convincing strategy for identifying the impact of rigidities. In a time series study, it will be difficult to avoid that the variance of the measured extent of rigidities is predominantly reflecting measurement error; moreover, the source of the variation threatens to remain unclear, since changes in policy are likely to be endogenous.

Searching for a convincing alternative for addressing the issue empirically, Nickell (1997) and Blanchard and Wolfers (1999) link the differential unemployment experience observed across countries to summary statistics of labor market rigidities and of the welfare state. Specifically, their empirical estimates rely on an index of employment protection, a labor standards index, the benefit replacement rate, the duration of benefits, and expenditures on active labor market policies, and on summary statistics of the structure of the systems of 
wage determination such as union density and union coverage. Based on their reasoning that it might be the interaction between unfavorable shocks and inadequate institutions that is important, not either of them by itself, Blanchard and Wolfers (1999) analyze, in particular, how the presence of labor market rigidities magnifies common macroeconomic shocks across countries.

These analyses find that as a whole, labor market rigidities indeed play an important role for a country's labor market performance, but they also yield a variegated picture about the magnitude and relevance of individual institutional aspects. This partially explains why the notoriously rigid West German labor market generates comparatively low unemployment rates, given the experience of other European economies. These studies also make clear that the central questions are not theoretical but are of an empirical nature. In the context of this paper, one has to pose the questions: what is the transition intensity of German workers between the states of employment and unemployment and by how much do these intensities vary across different individuals and over time?

Second, several influential studies have demonstrated that the analysis of gross worker flows and job flows provides important insights beyond analyses of the unemployment rate. Seminal studies include Clark and Summers (1979), Abowd and Zellner (1985), Blanchard and Diamond (1989, 1990), and Davis and Haltiwanger (1990, 1993). These empirical analyses have been complemented by theories of job flows and workers flows (Pissarides 1986, 1991, Mortensen and Pissarides 1994). The available evidence on German labor market flows is scarce (early papers are Boeri and Cramer 1992 and Burda and Wyplosz 1994, based on aggregate data). Recently, the cross-country perspective of the first strand of the literature has been applied to the analysis on gross worker flows. Cohen et al. (1998) compare labor market flows between France and the US, Schmidt (1998) extends this comparison to include Germany.

\section{Data on German Labor Market Flows}

The analysis in this paper rests on individual-level, monthly West German data for 1983 to 1994, drawn from sample "A" of the German Socio-Economic Panel GSOEP, covering households headed by a native German. The GSOEP is a panel survey of individuals that started in 1984 and provides one annual survey wave each year, yielding 12 waves of data by 1995. In the questionnaire, respondents were asked to report their major activity for each 
month of the preceding year ${ }^{2}$. This detailed information on individual activities was condensed in this analysis into three distinct labor market states, employment, unemployment, and out-of-the-labor-force. "Employed" refers to full-time work, part-time work, and vocational training, "unemployed" to registered unemployed, and "out-of-the-labor force" is the residual category, comprising among others schooling, military service, maternity leave, and retirement.

Due to construction of the survey, the survey wave of year, say, 1994 provides us with knowledge of the respondents' labor market state in each month from January 1993 to December 1993, and with information on gender, age, and educational attainment as of survey time in 1994. To construct data on monthly flows, I have extracted retrospective information on individuals' labor market state from the GSOEP for the months January/February 1983 to November/December 1994. Thus, the study rests on 143 pairs of adjacent months.

The analysis explicitly distinguishes individuals in 18 gender-age-education cells, with three age groups, 16-24, 25-49, and 50-64, and three education groups, low, medium, and high. The education of German workers with only a low or medium secondary schooling degree (Hauptschule or Realschule) is considered to fall into the low category. Individuals who either hold a high secondary schooling degree (Abitur) or any form of formal postsecondary education other than university or technical college, for instance a vocational training course, are categorized as having medium education. Finally, degree from a technical college (Fachhochschule) or a university qualifies respondents' education as being high ${ }^{3}$.

The individual-level data allow us to calculate (i) monthly employment, unemployment and non-participation rates and (ii) monthly transition rates between these states for workers in each demographic cell for each origin month from January 1983 to November 1994, and for each pair of months from January-February 1983 to NovemberDecember 1994. In this first pass through the data, calculations were performed for men and women separately, and also separately for each of the 9 demographic cells distinguished by the age-education interaction (sample sizes in each month vary between 2,800 and 4,000 for

\footnotetext{
${ }^{2}$ This is precisely the information used in Schmidt (1998). Retrospective information from the GSOEP has also been used for an analysis of the West German labor market by Steiner (1994) in the estimation of hazard rate models, and for East Germany by Lechner (1998) and Wolff (1998).

${ }^{3}$ The sample distribution of demographic characteristics is available from the author upon request.
} 
women, and 2,700 and 3800 for men, respectively). That is, there are 3 rates and 9 transition intensities in each month during the sampling period for each detailed demographic cell ${ }^{4}$.

The calculations in this first pass through the individual-level data provide the basis for the further analysis. The focus in this paper is on a second stage, the estimation of an empirical model for cell-specific average unemployment rates and transition intensities from employment to unemployment and from unemployment to employment, respectively, with a focus on long-term demographic differences. To explore the issue of cyclical sensitivity, the analysis will follow Schmidt (1998) in distinguishing four three-year sub-periods 1983-85, 1986-88, 1989-91, and 1992-94. The precise way of accounting for cyclical changes will be discussed in section 3 .

Overall, when compared to the figures in the official statistics, the unemployment rates derived from the GSOEP data appear quite low; several reasons could be held responsible for this phenomenon. First, the sample only covers native West Germans. Not only do immigrants display a substantially worse educational distribution than native workers (e.g. Schmidt 1997), it is quite conceivable that immigrants have a somewhat higher unemployment rate across all demographic strata. Second, by contrast to the procedure of the German Statistical Office, it is the population of all employed workers, including the selfemployed, that - together with the registered unemployed - forms the denominator of the calculations in this paper.

Third, there may be data problems such as recall bias or selectivity. Classification errors have played a major role in the literature on gross flow data (seminal papers are Abowd and Zellner 1985, Poterba and Summers 1986, and Poterba and Summers 1995). Most importantly, as a consequence of the request to list only the predominant activity of each month, respondents may omit brief spells of unemployment from their retrospective record, thus leading to an underestimate of the unemployment rates and of the transition rates into and out of unemployment (for evidence on this phenomenon for East Germany see Wolff 1998). A related problem is possible heaping, the concentration of mis-classified entries in a particular month (for evidence on the GSOEP see, for instance, Kraus and Steiner 1998).

\footnotetext{
${ }^{4}$ In some months, we may not observe workers in all origin states and all demographic cells. Results available from the author demonstrate that for instance among the few high-skilled young men and women, in the vast majority of the 143 months no one was unemployed; it was then impossible to calculate the corresponding transition rate from unemployment to any other state.
} 
Finally, it might well be that the panel data used here capture a particularly "stable" part of the population, in the sense that the fact of being observed throughout most of the sample period on one hand and employment rates and re-employment success on the other are systematically positively related. These problems should be addressed in future research. In this paper, emphasis will instead be on the formal characterization of unemployment rates and flow rates on the basis of the available data. In particular, the next section discusses an empirical representation for monthly unemployment rates that describes the long-term demographic structure of unemployment while also addressing issues of cyclical sensitivity. This framework will be extended to labor market flows in the fourth section. The corresponding estimates will then allow a formal assessment of the mechanics behind intertemporal fluctuations in unemployment rates.

\section{Unemployment Rates}

This section documents the estimation of an empirical model for unemployment rates. The model condenses the information derived in the first pass through the data while at the same time leaving considerable flexibility to analyze the cyclical sensitivity of the labor market success of observable demographic groups to macroeconomic shocks. Specifically, the analysis compares the cyclical experience of average German workers to that of women, unskilled workers, and young and old workers, respectively. The estimating equation for the average unemployment rate in demographic group $i(i=1, \ldots, 9$ for "a1e1", ...,"a1e3","a2e1", ..., "a3e3"), gender $g$ (male, female), month $m(m=1, \ldots, 12)$, and period $t(t=1, \ldots, 4)$ is

$$
\begin{aligned}
u_{\text {igmt }}= & \left(\alpha+\gamma \cdot 1_{\text {female }}\right)+\sum_{i \neq 5}\left(\beta_{i}+\delta_{i} \cdot 1_{\text {female }}\right)+\sum_{m \neq 6} \mu_{m}+ \\
& \sum_{t \neq 2} \tau_{t} \cdot\left(1+d_{f} \cdot 1_{\text {female }}+d_{u} \cdot 1_{\text {unskilled }}+d_{y} \cdot 1_{\text {young }}+d_{o} \cdot 1_{\text {old }}\right)+e_{\text {igmt }},
\end{aligned}
$$

where $e_{i g m t}$ is the corresponding error term. In effect, the cell-specific average unemployment rates that were derived in the first pass through the individual-level data for 18 demographic cells and 143 months $^{5}$ are decomposed into several constituent parts (for a similar approach see Blanchard and Wolfers 1999 and Hoynes 1999).

First, coefficient $\alpha$ captures the average unemployment rate of males in the core demographic group of 25-49 year old, medium-skilled workers in the baseline month June

\footnotetext{
5 Some 16 of the resulting 2574 observations had to be dropped, because no observation was available - all these 16 cells referred to young men with high education.
} 
during the baseline period 1986-88, whereas coefficient $\gamma$ expresses the differential unemployment experience of women in the same demographic cell, month and period. The variable $1_{\text {female }}$ is an indicator variable for the average unemployment rates of female workers. The coefficients $\beta_{i}$ describe the demographic structure of unemployment experienced by male workers, capturing deviations from the average value characterizing the core group. For instance, the average unemployment rate of young unskilled males (in any June of period 2) is $\left(\alpha+\beta_{1}\right)$. Similarly, coefficients $\delta_{i}$ express deviations of the female structure from that for males. That is, the estimated average unemployment rate of, say, old medium-skilled women (in the baseline period and month) is $\left(\left(\alpha+\beta_{8}\right)+\left(\gamma+\delta_{8}\right)\right)$.

Since the estimation is based on monthly cell averages, a set of monthly effects $\mu_{m}$ characterizes the seasonal structure of unemployment in terms of a differential to baseline month June. Estimates of the average unemployment experience of, say, young unskilled males in any, say, April of the baseline period 1986-88 is $\left(\alpha+\beta_{1}+\mu_{4}\right)$. Furthermore, the analysis distinguishes the four time periods 1983-85 to 1992-94; coefficients $\tau_{t}$ express the average deviation of unemployment rates for any demographic cell in period $t$ from their corresponding value in the baseline period. For instance, male workers in the core in month November of the fourth period 1992-94 are estimated to experience an average unemployment rate of $\left(\alpha+\mu_{11}+\tau_{4}\right)$.

Next to describing the average structure of unemployment in the four principal periods, the major emphasis in this analysis is on the differential cyclical experience of what are generally referred to as problem groups. In the regression, interaction terms capture how the evolution of their performance compares formally to the cyclical experience of the average worker. Specifically, in addition to their direct impact, the average coefficients $\tau_{t}$ are interacted with four loading factors, $d_{f}$ for women, $d_{u}$ for unskilled workers, $d_{y}$ for young and $d_{o}$ for old workers, respectively. In expression (1), the indicator variables $1_{\text {unskilled }}, 1_{\text {young }}$, and $l_{\text {old }}$ are defined accordingly. A positive interaction coefficient, for instance a positive $d_{u}$, would indicate that for the corresponding group, here unskilled workers, the cyclical swings captured by $\tau_{t}$ are emphasized, whereas a negative value would indicate that this group experiences more moderate cyclical swings than the average worker. A value of -1 would even imply complete disattachment from the cycle.

Since estimation is performed on grouped data, with underlying sample sizes - and thus the precision of the individual cells' averages - varying considerably, in this second-step regression, cell averages are weighted by the corresponding labor force shares. This strategy 
does not only account for differences in the precision of cell averages, it also attributes a higher weight to large demographic cells in the calculation of common slope parameters such as, say, $\tau_{t}$.

Table 1 reports the results of applying this model to the observed unemployment rates $^{6}$. Over the sampling period, male and female unemployment rates have, on average, been approximately $4 \%$ and 5\%, respectively. The estimation of equation (1) reveals that these average figures hide a substantial heterogeneity across demographic cells. First, average female unemployment rates in the core group are significantly higher than those of core male workers. Second, there is a distinct demographic structure in male unemployment rates. Unskilled workers of any age, and medium-skilled young and old workers experience higher unemployment rates than the male core group. Consequently, there is a distinct profile in education. This disadvantage is most pronounced for the medium-aged and old unskilled workers. By contrast, medium-aged workers who graduated from a university or from a technical college (high-skilled workers) experience a significantly lower average unemployment rate.

As was already indicated by Figure 1, the female unemployment structure is considerably more homogenous, the education profile is less pronounced. While the problematic position of young unskilled women and young unskilled men - as compared to the respective gender core - is comparable, medium-aged unskilled, old unskilled, and young medium-skilled women do not follow their male counterparts in displaying a comparatively high unemployment rate. Instead, the corresponding coefficients offset much of the differential effects implied by the male coefficients. On the other hand, for two cells the female rates for women deviate from this quite homogeneous structure. The unsatisfactorily high unemployment rate of old medium-skilled workers is even more pronounced, while old skilled women experience a particularly low unemployment rate.

The average intertemporal developments can be summarized by two observations. First, there was a steady improvement in unemployment rates during the first three periods. The average unemployment rate in the first period 1983-85 was higher, that in the third period 1989-91 considerably lower than for the baseline period 1986-88. Second, the strong performance of the third period, feeding on the re-unification boom, was not repeated in the fourth period 1992-94. Instead, average unemployment rates almost returned to the level of

\footnotetext{
${ }^{6}$ In the Appendix, the corresponding linear regression models without the loading factors are reported for unemployment rates and for the transition intensities discussed in section 4. In all three cases, the qualitative results on all other variables are retained across specifications.
} 
period 2, although they remained slightly lower. That is, judging on the basis of these estimates, the performance of the German labor market deteriorated in recent years, but only when compared to the boom period of 1989-91, this seems alarming.

The cyclical sensitivity of problem groups is captured in the four loading factors displayed in the middle of Table 1 . Women do indeed experience relatively pronounced swings in their unemployment rates over the cycle. Their unemployment rates are raised moderately above average in an economic downswing and lowered moderately more than for the average worker in an economic recovery. By contrast, unskilled workers experience somewhat less pronounced swings than the average worker. As was demonstrated by the average coefficients discussed above, their unemployment rates are in general relatively high.

The estimate of loading factor $d_{u}$ suggests, however, that their unemployment rates are not raised as much as those of the average worker in an economic downturn. On the other hand, according to these estimates, unskilled workers also do not enjoy a very pronounced positive development in their unemployment rates in an economic upswing. Recall from section 2 that for the purposes of this study unskilled workers only comprise individuals without any formal post-secondary education and without a completed secondary education in the highest schooling tier (Abitur). Less than one out of five workers in the sample fall in this category.

Compared to these relatively moderate loading factors, those of young and of old workers indicate quite strong, albeit in their implications exactly opposite deviations from the cyclical experience of the average worker. The estimates imply that young workers experience very pronounced cyclical swings. In boom periods their unemployment rates decline by approximately triple the amount of that for the average worker. In economic downswings, however, their unemployment rate also rises by a threefold magnitude.

This observation qualifies the notion of the comparatively successful German youth labor market. While German youth unemployment rates are relatively low in a comparison across OECD countries, according to these estimates young workers (approximately one out of five German workers) are considerably more vulnerable to cyclical swings than the average worker. If (as was indicated by the discussion in section 2) the data fail to capture a substantial fraction of relatively short unemployment spells, and if it is young workers who disproportionately often experience such short unemployment spells, then this estimate even understates the cyclical sensitivity of young workers' unemployment rates.

By contrast, the estimates reported in Table 1 imply that old workers (also approximately one fifth of the sample) are completely detached from the economic cycle. The 
estimated loading factor for old workers is statistically indistinguishable from -1 and thus completely offsets aggregate cyclical swings. Whether this is mainly a consequence of unchanged fundamentals - transition intensities from employment to unemployment and vice versa - or rather due to other offsetting fluctuations, will be explored in the next section of the paper.

Finally, the estimated seasonal factors imply that the month of June, together with May, and also with the months of April, September and October, is a particularly lowunemployment month, whereas the winter months November to March, but also the summer months July and August are typically high-unemployment months. The latter phenomenon seems to defy any of the traditional bad weather justifications for seasonal fluctuations in unemployment. In the next section, these seasonal patterns will also be decomposed into fluctuations in flow intensities from employment to unemployment and from unemployment to employment.

\section{Labor Market Flows}

\section{Rates of Job Loss}

In this section the model embodied in equation (1) is extended to flows from employment to unemployment $f^{e u}$ and from unemployment to employment $f^{u e}$, respectively. As in section 3, the analysis is based on the cell averages that were derived in the first pass through the data described in section 2. Estimated transition rates in demographic group $i(i=1, \ldots, 9)$, gender $g$ (male, female), month $m(m=1, \ldots, 12)$, and period $t(t=1, \ldots, 4)$ form the basis for these second-step estimates, while leaving the right-hand side of expression (1) unchanged.

In contrast to the previous section, the appropriate weighting factors in the estimations are derived by forming the product between the corresponding labor force share of the demographic group and the fraction of workers in this demographic cell who are in the respective origin state in the observed month. Thus, again, the estimation of the empirical model for these flow rates intends to condense the information in the data while at the same time leaving considerable flexibility to analyze cyclical sensitivity to macroeconomic shocks. Again, the analysis compares the cyclical experience of average German workers to that of women, of unskilled workers, and of young and old workers, respectively. The results on monthly transition intensities between the states of employment and unemployment are presented in Tables 2 and 3.

Table 2 displays the results from modeling transition rates from employment to unemployment, referred to in the table as rates of job loss. In the average pair of months in 
the sampling period, approximately $0.4 \%$ of employed male and female workers went into unemployment. As it was demonstrated to be the case for unemployment rates, the average figures are hiding a substantial heterogeneity across demographic cells. Among men, employment is less stable for unskilled workers, but also for young medium-skilled workers. Recall that these transition intensities do not capture moves from employment to nonparticipation, that is education, military service and the like. By contrast, old medium-skilled and high-skilled workers enjoy significantly higher job stability, as do medium-aged highskilled workers.

Women in the core demographic cell display the same job loss rates as their male counterparts. For female workers, the demographic structure is more homogeneous than for males, however. For medium-aged and old unskilled women, for young medium-skilled women, and for medium-aged high-skilled women - all demographic groups with significant deviations from the core for male workers - we observe approximately the same job loss rates as for the core group. Employment to non-participation transitions are a much larger component of job loss than transitions into unemployment for both male and female workers (not in the tables), but clearly more drastically for women.

Over time, job loss rates change in a manner consistent with the fluctuations in unemployment rates that were discussed in the previous section. During the first three subperiods, job loss rates for the typical worker declined steadily, by roughly a tenth of a percentage point per three-year period. To illustrate the quite substantial impact of even such a numerically small change, let us briefly assess the implied difference for the limiting unemployment rate. Holding all other values of the transition matrix constant at the average sample values, an increase in the job loss rate of this magnitude translates into a rise in the limiting unemployment rate of more than $20 \%$ of its original value. In the final period 199294, much of this decline in job loss rates was reversed. In fact, according to these estimates, the job loss rate in this fourth period was even significantly larger than it had been in the baseline period 1986-88.

The estimated loading factors imply that the cyclical swings of job loss rates of women and of old workers are basically in line with that of the average worker. By contrast, the job loss rates of unskilled workers - who happen to experience high job loss rates on the average - appear not to display any cyclical behavior whatsoever. Instead, the corresponding estimate of $d_{u}$ is insignificantly different from -1 , thus completely offsetting positive as well as negative shocks to overall job loss rates. 
The job loss rates of young workers, however, are very sensitive to the cycle. For young workers cyclical swings are amplified to approximately double the magnitude experienced by the average worker. Regarding measurement issues, one might again conjecture that the omission of brief spells of unemployment - if they were indeed falling disproportionately on young workers - even led to an understatement of the cyclical sensitivity of young workers' job loss rates.

Finally, the estimated seasonal factors suggest that apart from the month of December the month of June - demonstrated in the previous section to be the major low-unemployment month of the year - is indeed the month with the highest job loss rates of the year. In particular, the adjacent months April and May, and July and August are months of considerably higher job stability. Estimated transition intensities in December might be overstated due to the potential problem of heaping. The seasonal pattern between April and August might also reflect measurement problems, with June being somewhat of a focal point in the recollection of individual respondents.

A structural explanation seems more likely to capture the underlying reasons, however. Either employers find it to be more beneficial, on average, to release workers before the comparatively unproductive time of summer vacations, a demand-side explanation, or workers are less reluctant to quit their jobs in the beginning of the summer, an explanation focusing on labor supply. Both behavioral patterns would be consistent with the data being analyzed here.

\section{Re-employment Rates}

On average, during the sampling period more than $9 \%$ of all unemployed German men left unemployment each month to take up employment. Table 3 displays the results of applying the non-linear empirical model (1) to transition intensities from unemployment to employment ${ }^{7}$. Female re-employment rates in the labor force core are considerably lower than those of males. The estimates imply that they are indeed only approximately half of the male transition intensities in this demographic group. This large difference would be consistent with less success in generating job offers, but also with higher reservation wages preventing the acceptance of forthcoming job offers.

For male workers, it is the medium-age unskilled and old workers of any skill who display particularly low re-employment rates. In fact, based on these estimates, for old male workers the probability of returning into employment is almost zero. As for the male-female 
difference in the demographic core group, it is impossible to infer from these estimates alone whether this low re-employment rate is a purely demand-driven phenomenon. Furthermore, since we do not observe any counterfactual situation nothing is implied by these estimates regarding the potential effects of early retirement schemes. By contrast to old male workers, young medium-skilled and high-skilled, and medium-aged high-skilled male workers face relatively high re-employment rates.

For female workers, coefficients on the unskilled and on old medium-skilled and high-skilled suggest that the substantial heterogeneity in male re-employment intensities is somewhat moderated for women. Closer inspection reveals, however, that old female workers also display an almost negligible re-employment rate, just as old men. The small value for women in the demographic core just did not leave as much room for negative deviations as it did for men, leading to a mechanical compensatory realization of estimated female deviations.

Cyclical swings in re-employment rates are statistically less well-established than those for unemployment rates or rates of job loss. Nevertheless, the same general pattern emerges from the estimates. There was a steady improvement in re-employment rates during the first three sub-periods, with the difference between the first and the third period being statistically significant. Between the third period 1989-91 and the fourth period 1992-94, one can observe a dramatic (and clearly statistically significant) reversal, with an estimated drop in average re-employment rates of more than one percentage point.

As an illustration, let us again briefly assess the implied difference for the limiting unemployment rate. Holding all other values of the transition matrix constant at the average sample values, a decrease in the re-employment rate by one percentage point translates into a rise in the limiting unemployment rate of approximately $10 \%$. Combining a tenth of a percentage point increase in job loss rates with a one percentage point decrease in reemployment rates would even result in a limiting unemployment that is raised by one third of its original limiting value.

None of the estimated loading factors is statistically significant at conventional values. If anything emerges from these estimates, then the facts that the point estimate of the loading factor for unskilled workers again indicates disattachment from the cycle, and that young workers are very sensitive to the cycle. Following the reasoning laid out above, measurement errors for short unemployment spells might even lead to an understatement of the cyclical sensitivity of young workers. 
Finally, as it was the case for rates of job loss, the month of June is again found to be very special. With the only clear exception of the month of November and together with January and October, June is the month with the lowest estimated re-employment rates. Now the low estimated rates for October and November and the very high estimated rate in December are indicative of the presence of heaping from the tenth and eleventh month of the year to its final month. Since these months are therefore comparable, in terms of estimated reemployment intensities, to the months February to May and July to September, the month of June stands out even more.

As the data at hand are only able to reveal equilibrium outcomes, it is impossible to conclude at the present time whether this phenomenon reflects a shortage of job offers or relatively high reservation wages, or a measurement issue beyond the realm of the current analysis. However, it seems to be an interesting topic for further investigation of German gross worker flows.

\section{Discussion}

Using a formal empirical model, this paper parsimoniously characterizes the longterm structure of unemployment rates and flow intensities, as well as their cyclical behavior across 18 demographic cells for the German labor market. In particular, the model captures cyclical behavior by a series of loading factors translating unobserved aggregate shocks to the labor market into observed fluctuations in cell-specific unemployment rates and transition intensities. The estimates use monthly data on worker flows between three principal labor market states, employment, unemployment, and out-of-the-labor force, and on detailed information regarding major demographic characteristics, gender, age, and education from the German Socio-Economic Panel GSOEP for the period 1983 to 1994.

The empirical results demonstrate the considerable demographic heterogeneity of unemployment rates over the long-term, and trace this heterogeneity back to the comparable heterogeneity of both rates of job loss and rates of re-employment. In general, the simultaneous consideration of age, gender, and education is necessary to provide a sufficient account of the demographic structure of German unemployment. For instance, the combination of low skills and high age turns out to be a particularly dismal combination for job stability, re-employment success and average unemployment rates.

Moreover, the estimates imply that in addition to the considerable long-term differences displayed by the various demographic groups, the structure of unemployment and that of transition intensities vary over the cycle. In particular, across all groups of workers, 
the West German labor market displayed a steady improvement between the early 1980s and the end of the re-unification boom in the early 1990s, and a sharp deterioration thereafter. Judging from the estimates, cyclical swings, positive as well as negative, were particularly pronounced for young workers, whereas unskilled workers and old workers were far less affected by cyclical movements.

Finally, the cyclical behavior of unemployment rates on one hand and of transition intensities between employment and unemployment on the other does not quite add up for women and old workers. Over the cycle, female workers display relatively pronounced swings in unemployment rates, yet the fluctuations in their flow intensities are rather modest. This is consistent with an added-worker idea implying a counter-cyclical participation behavior of women. By contrast, old workers display only moderately dampened cyclical swings in their flow intensities, yet their unemployment rates seem to be completely disattached from the cycle. This pattern is consistent with a discouraged worker argument. These considerations indicate that movements in and out of non-participation play an important role over the cycle.

As a further illustration of these problems, Figure 2 plots average unemployment rates in each demographic cell for each of the four sub-periods against the corresponding average employment rates, separately for male and female workers. On the average, groups of female workers displaying a high (low) employment rate in the long run, quite uniformly also display low (high) unemployment rates, generating a relatively steep average profile. Within demographic cells, however, non-participation appears to be an important escape route for women over the cycle. More formally, the average within-group correlation of the four sub-period averages is -0.53 for male workers, but only -0.20 for female workers. A value of -1 would indicate that falling employment is not compensated whatsoever by compensatory moves out of the labor force.

Further exploration of the demographic structure of non-participation and its behavior over the cycle would tie in well with the long debate on whether unemployment and out-ofthe-labor force are indeed distinct labor force states (a recent stab at the problem is Jones and Riddell 1999). In this literature, it is tested whether transition intensities into employment are of comparable magnitudes for unemployed workers and (sub-sets of) non-participants. The perspective that would be taken in an extension of this analysis should be somewhat different, however: in assessing the severity of unemployment problems over the cycle, nonemployment might be a serious escape route whose cyclical importance should be analyzed jointly with flows between employment and unemployment. 


\section{References}

Abowd, J. and A. Zellner (1985) Estimating Gross Labor Force Flows, Journal of Economic and Business Statistics 3, 254-283.

Berger, H. (1998) Regulation in Germany. Some Stylized Facts About its Time Path, Causes, and Consequences, Zeitschrift für Wirtschafts- und Sozialwissenschaften 118, 185-220.

Blanchard, O. and P. Diamond (1989) The Beveridge Curve, Brookings Papers on Economic Activity 1989:1, 1-76.

Blanchard, O. and P. Diamond (1990) The Cyclical Behavior of Gross Flows of Workers in the US, Brookings Papers on Economic Activity 1990:2, 81-155.

Blanchard, O. and J. Wolfers (1999) The Role of Shocks and Institutions in the Rise of European Unemployment: The Aggregate Evidence, mimeo.

Boeri, T. and U. Cramer (1992) Employment Growth, Incumbents and Entrants: Evidence From Germany, International Journal of Industrial Organization 10, 343-363.

Burda, M. and C. Wyplosz (1994) Gross Worker and Job Flows in Europe, European Economic Review 38, 1287-1315.

Clark, K. and L. Summers (1979) Labor Market Dynamics and Unemployment: A Reconsideration, Brookings Papers on Economic Activity 1979:1, 13-60.

Cohen, D. A. Lefranc and G. Saint-Paul (1997) French Unemployment: A Transatlantic Perspective, Economic Policy 25, 267-291.

Davis, S. and J. Haltiwanger (1990) Gross Job Creation and Destruction: Microeconomic Evidence and Macroeconomic Implications, NBER Macroeconomics Annual 5, 123-168.

Davis, S. and J. Haltiwanger (1993) Gross Job Creation, Gross Job Destruction and Job Reallocation, Quarterly Journal of Economics 107, 819-863.

Hoynes, H. (1999) The Employment, Earnings, and Income of Less Skilled Workers Over the Business Cycle, forthcoming in: Card, D. and R. Blank (eds.) Finding Jobs: Work and Welfare Reform, Russel Sage Foundation.

Jones, S. R. G. and W. C. Riddell (1999) The Measurement of Unemployment: An Empirical Approach, Econometrica 67, 147-162.

Kraus, F. and V. Steiner (1998) Modeling Heaping Effects in Unemployment Duration Models - With an Application to Retrospective Event Data in the German Socio-Economic Panel, Jahrbücher für Nationalökonomie und Statistik 217, 550-573.

Lechner, M. (1998) Training the East German Labour Force, Heidelberg: Physica-Verlag.

Mortensen, D. and C. Pissarides (1994) Job Creation and Job Destruction in the Theory of Unemployment, Review of Economic Studies 61, 397-415. 
Nickell, S. (1997) Unemployment and Labor Market Rigidities: Europe versus North America, Journal of Economic Perspectives 11, 55-74.

Pissarides, C. (1986) Unemployment and Vacancies in Britain, Economic Policy 3, 499-559.

Pissarides, C. (1991) Equilibrium Unemployment Theory, Oxford: Basil Blackwell.

Poterba, J. and L. Summers (1986) Reporting Errors and Labor Market Dynamics, Econometrica 54, 1319-1338.

Poterba, J. and L. Summers (1995) Unemployment Benefits and Labor Market Transitions: A Multinomial Logit Model with Errors in Classification, The Review of Economics and Statistics 77, 207-216.

Schmidt, C. M. (1997) Immigrant Performance in Germany: Labor Earnings of Ethnic German Migrants and Foreign Guest-Workers, The Quarterly Review of Economics and Finance 37, 379-397.

Schmidt, C. M. (1998) Persistence and the German Unemployment Problem: Empirical Evidence on German Unemployment Flows, CEPR Discussion Paper No. 2057.

Siebert, H. (1997) Labor Market Rigidities: At the Root of Unemployment in Europe, Journal of Economic Perspectives 11, 37-54.

Statistisches Bundesamt (1997): Volkswirtschaftliche Gesamtrechnungen, Fachserie 18, Reihe 1.3: 1996 - Hauptbericht, Wiesbaden.

Steiner, V. (1994) Labour Market Transitions and the Persistence of Unemployment - West Germany 1983 - 1992, Discussion Paper No. 94-20, ZEW Mannheim.

Wolff, J. (1998) Errors of Recall and Retrospectively Collected Unemployment Spell Data of the German Socio-Economic Panel-East, in: Selected Topics in Unemployment Duration in two Economies in Transition: East-Germany and Hungary, Ph.D. thesis, European University Institute, Florence.

Zimmermann, K. F., H. Hinte, and A. Thalmeier (1999) Ursachen und Wege zur Bekämpfung von Arbeitslosigkeit, mimeo. IZA-Bonn. 


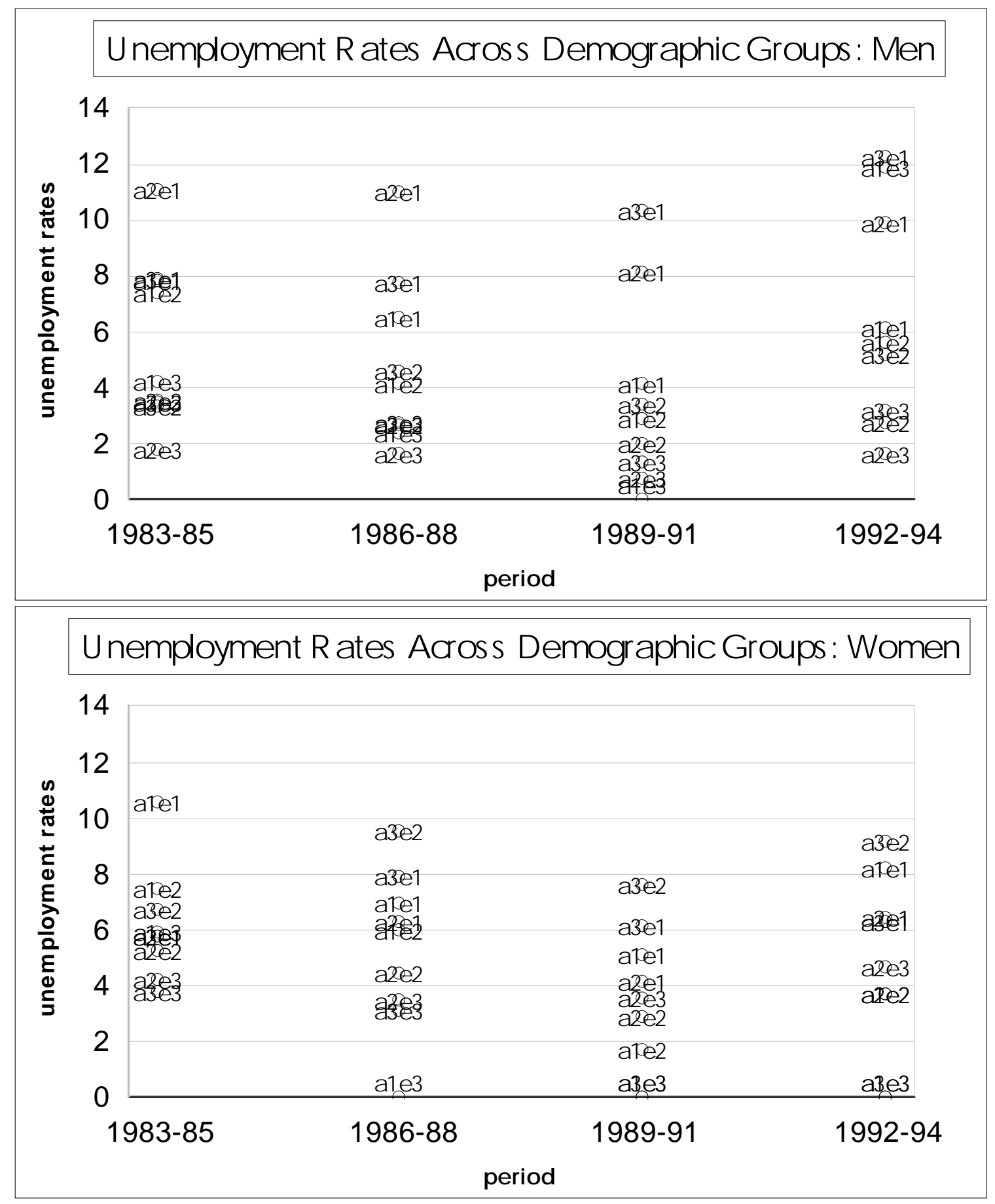

Figure 1: The Heterogeneity of Unemployment Rates Across Demographic Groups 

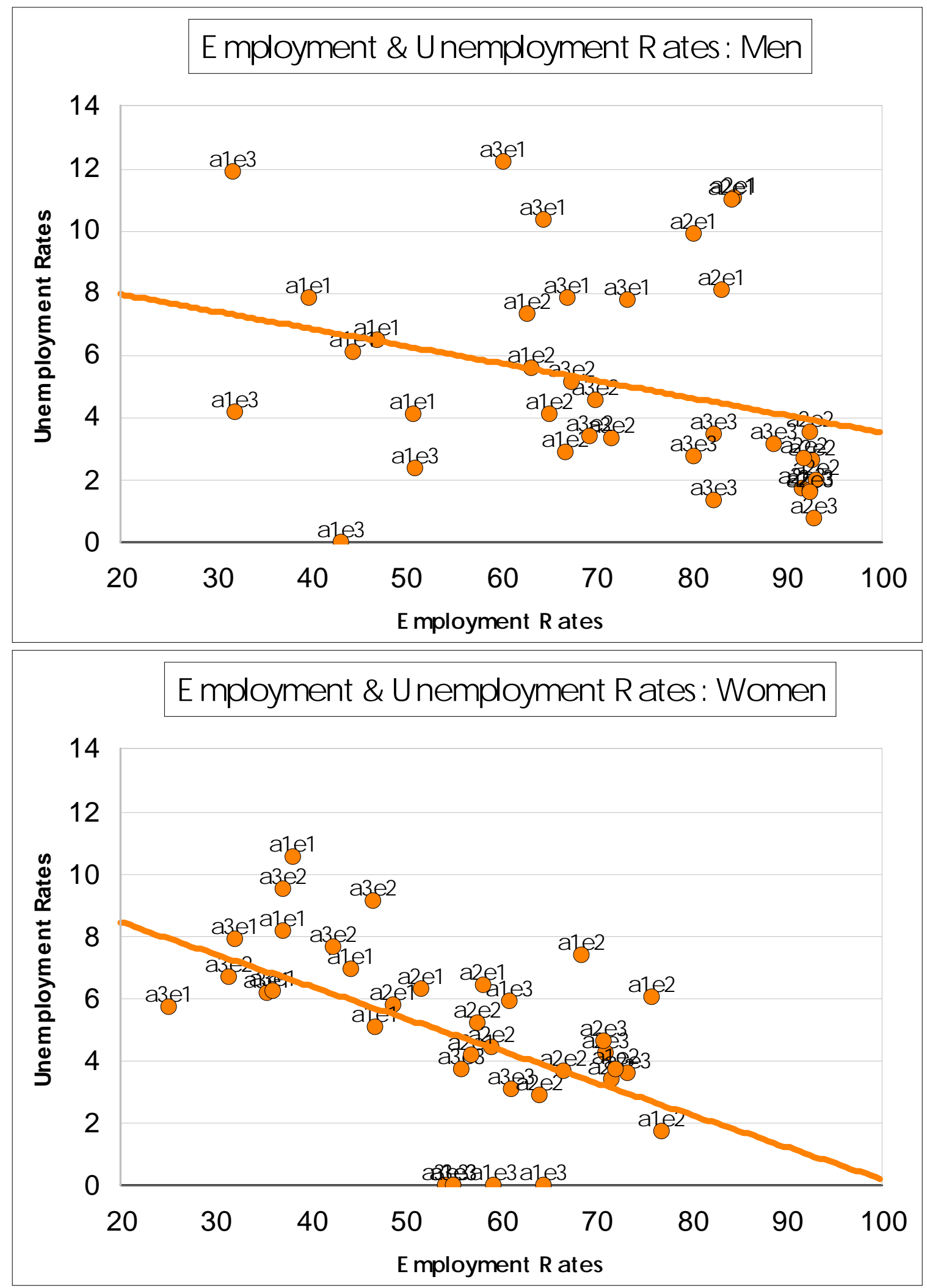

Figure 2: Employment vs. Unemployment Rates Across Demographic Groups 
Table 1: Unemployment Rates - the Cyclical Sensitivity of Problem Groups

\section{Core Values}

$\begin{array}{llll}\text { Constant } & 2.5514 & \text { Female Deviation } & 1.3514\end{array}$

$(23.872)$

(16.146)

Demographics: Deviations from the Core

\begin{tabular}{l|lll} 
& Unskilled & Medium-skilled & High-skilled \\
\hline Young (16-24) & 3.5671 & 2.3655 & 1.1989 \\
& $(21.574)$ & $(16.636)$ & $(0.946)$ \\
Medium (25-49) & 7.2671 & - & -1.2615 \\
& $(45.520)$ & & $(-10.808)$ \\
Old (50-64) & 6.6321 & 1.3060 & -0.1204 \\
& $(30.018)$ & $(12.285)$ & $(0.601)$
\end{tabular}

Demographics: Female Deviations From Male Demographics

\begin{tabular}{l|lll} 
& Unskilled & Medium-skilled & High-skilled \\
\hline Young (16-24) & 0.1543 & -1.4567 & -3.3074 \\
& $(0.665)$ & $(-7.838)$ & $(-2.000)$ \\
Medium (25-49) & -5.6973 & - & 1.2683 \\
& $(-26.696)$ & & $(6.120)$ \\
Old (50-64) & -4.2195 & 2.9712 & -2.4128 \\
& $(-15.453)$ & $(16.360)$ & $(-5.487)$
\end{tabular}

Regimes

\begin{tabular}{llll} 
Regime 1: 1983-85 & Regime 2: 1986-88 & Regime 3: 1989-91 & Regime 4: 1992-94 \\
\hline 0.6527 & - & -0.8649 & -0.1141 \\
$(10.050)$ & & $(-11.394)$ & $(-2.310)$
\end{tabular}

\section{Cyclical Sensitivity: Loading Factors}

\begin{tabular}{llll} 
Women & Unskilled & Young & Old \\
\hline 0.4183 & -0.2692 & 2.0731 & -1.0578 \\
$(3.399)$ & $(-2.043)$ & $(8.618)$ & $(-8.738)$
\end{tabular}

\begin{tabular}{llll} 
January & February & $\begin{array}{c}\text { Seasonal Factors } \\
\text { March }\end{array}$ & April \\
\hline 0.6559 & 0.6611 & 0.4419 & 0.2123 \\
$(4.978)$ & $(5.019)$ & $(3.355)$ & $(1.609)$ \\
May & June & July & August \\
\hline 0.0039 & - & 0.2757 & 0.2489 \\
$(0.030)$ & & $(2.091)$ & $(1.892)$ \\
September & October & November & December \\
\hline 0.1243 & 0.1334 & 0.2701 & 0.3170 \\
$(0.946)$ & $(1.016)$ & $(2.055)$ & $(2.355)$
\end{tabular}

\section{Diagnostics}

$\begin{array}{llll}\text { Number of Obs. } & 2558 & \text { Adj. R-squared } & 0.7281\end{array}$

The model was estimated via Nonlinear Least Squares. Asymptotic t-Values in parentheses. 
Table 2: Rates of Job Loss - the Cyclical Sensitivity of Problem Groups

\section{Core Values}

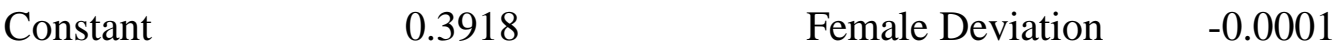

(11.460)

$(-0.004)$

Demographics: Deviations from the Core

\begin{tabular}{l|lll} 
& Unskilled & Medium-skilled & High-skilled \\
\hline Young (16-24) & 0.3793 & 0.6233 & 0.1200 \\
& $(6.234)$ & $(13.907)$ & $(0.250)$ \\
Medium (25-49) & 0.3120 & - & -0.1365 \\
& $(6.461)$ & & $(-4.199)$ \\
Old (50-64) & 0.2070 & -0.0575 & -0.1414 \\
& $(2.860)$ & $(-1.810)$ & $(-2.452)$
\end{tabular}

Demographics: Female Deviations From Male Demographics

\begin{tabular}{l|lll} 
& Unskilled & Medium-skilled & High-skilled \\
\hline Young (16-24) & -0.0247 & -0.2295 & -0.5231 \\
& $(-0.272)$ & $(-3.835)$ & $(-0.880)$ \\
Medium (25-49) & -0.2310 & - & 0.2146 \\
& $(-3.339)$ & & $(3.373)$ \\
Old (50-64) & -0.3093 & 0.0287 & -0.1460 \\
& $(-3.005)$ & $(0.417)$ & $(-0.970)$
\end{tabular}

Regimes

\begin{tabular}{llll} 
Regime 1: 1983-85 & Regime 2: 1986-88 & Regime 3: 1989-91 & Regime 4: 1992-94 \\
\hline 0.1063 & - & -0.1084 & 0.0448 \\
$(4.270)$ & & $(-4.367)$ & $(1.986)$
\end{tabular}

\section{Cyclical Sensitivity: Loading Factors}

\begin{tabular}{llll} 
Women & Unskilled & Young & Old \\
\hline-0.0266 & -0.9253 & 1.1617 & -0.2740 \\
$(-0.113)$ & $(-2.823)$ & $(2.876)$ & $(-0.970)$
\end{tabular}

Diagnostics

$\begin{array}{llll}\text { Number of Obs. } & 2558 & \text { Adj. R-squared } & 0.2770\end{array}$

The model was estimated via Nonlinear Least Squares. Asymptotic t-Values in parentheses. 
Table 3: Re-employment Rates - the Cyclical Sensitivity of Problem Groups

\section{Core Values}

Constant $\quad 9.3910 \quad$ Female Deviation $\quad-4.9274$

(13.091)

$(-8.462)$

Demographics: Deviations from the Core

\begin{tabular}{l|lll} 
& Unskilled & Medium-skilled & High-skilled \\
\hline Young (16-24) & -1.0164 & 6.0547 & 22.0138 \\
& $(-1.061)$ & $(6.253)$ & $(2.774)$ \\
Medium (25-49) & -6.2237 & - & 4.0765 \\
& $(-8.374)$ & & $(3.422)$ \\
Old (50-64) & -8.2037 & -9.2903 & -8.5523 \\
& $(-8.332)$ & $(-13.467)$ & $(-5.486)$
\end{tabular}

Demographics: Female Deviations From Male Demographics

\begin{tabular}{l|lll} 
& Unskilled & Medium-skilled & High-skilled \\
\hline Young (16-24) & 3.5577 & 1.6828 & -17.4280 \\
& $(2.924)$ & $(1.483)$ & $(-1.450)$ \\
Medium (25-49) & 4.8574 & - & -0.5942 \\
& $(4.466)$ & & $(-0.365)$ \\
Old (50-64) & 2.5943 & 3.5867 & 5.0660 \\
& $(1.980)$ & $(3.564)$ & $(1.189)$
\end{tabular}

Regimes

\begin{tabular}{llll} 
Regime 1: 1983-85 & Regime 2: 1986-88 & Regime 3: 1989-91 & Regime 4: 1992-94 \\
\hline-0.5047 & - & 0.9230 & -0.5604 \\
$(-1.573)$ & & $(1.747)$ & $(-1.566)$
\end{tabular}

\section{Cyclical Sensitivity: Loading Factors}

\begin{tabular}{llll} 
Women & Unskilled & Young & Old \\
\hline-0.3292 & -0.7645 & 4.4570 & -0.3928 \\
$(-0.616)$ & $(-1.142)$ & $(1.591)$ & $(-0.619)$
\end{tabular}

Diagnostics

$\begin{array}{llll}\text { Number of Obs. } & 2166 & \text { Adj. R-squared } & 0.3252\end{array}$

The model was estimated via Nonlinear Least Squares. Asymptotic t-Values in parentheses. 
APPENDIX 
Table A1: Unemployment Rates - the Baseline Model

\begin{tabular}{llll}
\hline \multirow{2}{*}{ Constant } & \multicolumn{3}{c}{ Core Values } \\
& $\begin{array}{l}2.6723 \\
(22.084)\end{array}$ & Female Deviation & 1.3048 \\
& \multicolumn{3}{c}{ Demographics: Deviations from the Core } \\
& Unskilled & Medium-skilled & High-skilled \\
\hline Young (16-24) & 3.4578 & 2.2507 & 1.3234 \\
& $(20.351)$ & $(16.140)$ & $(0.976)$ \\
Medium (25-49) & 7.2810 & - & -1.2600 \\
Old (50-64) & $(42.729)$ & & $(-10.086)$ \\
& 6.7795 & 1.4136 & 0.0052 \\
& $(29.183)$ & $(13.051)$ & $(0.024)$
\end{tabular}

\section{Demographics: Female Deviations From Male Demographics}

\begin{tabular}{l|lll} 
& Unskilled & Medium-skilled & High-skilled \\
\hline Young (16-24) & 0.1464 & -1.1184 & -3.2194 \\
& $(0.590)$ & $(-7.284)$ & $(-1.820)$ \\
Medium (25-49) & -5.6753 & - & 1.2611 \\
& $(-24.851)$ & & $(5.685)$ \\
Old (50-64) & -4.1936 & 3.0194 & -2.4370 \\
& $(-14.353)$ & $(15.550)$ & $(-5.177)$
\end{tabular}

Regimes

\begin{tabular}{llll} 
Regime 1: 1983-85 & Regime 2: 1986-88 & Regime 3: 1989-91 & Regime 4: 1992-94 \\
\hline 0.5704 & - & -1.3302 & -0.0595 \\
$(6.930)$ & & $(-16.403)$ & $(-0.729)$
\end{tabular}

Seasonal Factors

\begin{tabular}{llll} 
January & February & March & April \\
\hline 0.6546 & 0.6601 & 0.4412 & 0.2115 \\
$(4.642)$ & $(4.682)$ & $(3.130)$ & $(1.498)$ \\
May & June & July & August \\
\hline 0.0039 & - & 0.2748 & 0.2500 \\
$(0.027)$ & & $(1.948)$ & $(1.775)$ \\
September & October & November & December \\
\hline 0.1264 & 0.1362 & 0.2731 & 0.3375 \\
$(0.899)$ & $(0.969)$ & $(1.941)$ & $(2.342)$
\end{tabular}

Diagnostics

$\begin{array}{llll}\text { Number of Obs. } & 2558 & \text { Adj. R-squared } & 0.6886\end{array}$

Results of a linear regression model; $t$-Values in parentheses. 
Table A2: Rates of Job Loss (Employment to Unemployment) - the Baseline Model

\begin{tabular}{llcl}
\hline \hline \multirow{2}{*}{ Constant } & \multicolumn{3}{c}{ Core Values } \\
& 0.3895 & Female Deviation & -0.0018 \\
& $(11.155)$ & & $(-0.069)$ \\
& \multicolumn{3}{c}{ Demographics: Deviations from the Core } \\
& Unskilled & Medium-skilled & High-skilled \\
\hline Young (16-24) & 0.3812 & 0.6354 & 0.1390 \\
\multirow{4}{*}{ Medium } & $(6.247)$ & $(14.951)$ & $(0.288)$ \\
Old & 0.2996 & - & -0.1369 \\
& $(6.421)$ & & $(-4.200)$ \\
& 0.2006 & -0.0599 & -0.1463 \\
& $(2.832)$ & $(-1.898)$ & $(-2.536)$
\end{tabular}

Demographics: Female Deviations From Male Demographics

\begin{tabular}{l|lll} 
& Unskilled & Medium-skilled & High-skilled \\
\hline Young (16-24) & -0.0231 & -0.2302 & -0.5008 \\
& $(-0.253)$ & $(-3.835)$ & $(-0.840)$ \\
Medium (25-49) & -0.2270 & - & 0.2154 \\
& $(-3.272)$ & & $(3.375)$ \\
Old (50-64) & -0.2989 & 0.0291 & -0.1427 \\
& $(-2.897)$ & $(0.422)$ & $(-0.944)$
\end{tabular}

Regimes

\begin{tabular}{llll} 
Regime 1: 1983-85 & Regime 2: 1986-88 & Regime 3: 1989-91 & Regime 4: 1992-94 \\
\hline 0.1947 & - & -0.1077 & 0.0644 \\
$(3.866)$ & & $(-4.504)$ & $(2.677)$
\end{tabular}

Seasonal Factors

\begin{tabular}{llll} 
January & February & March & April \\
\hline-0.1712 & -0.1870 & -0.0757 & -0.2591 \\
$(-4.110)$ & $(-4.489)$ & $(-1.818)$ & $(-6.212)$ \\
May & June & July & August \\
\hline-0.2094 & - & -0.1286 & -0.1786 \\
$(-5.024)$ & & $(-3.086)$ & $(-4.300)$ \\
September & October & November & December \\
\hline-0.0568 & -0.0606 & -0.0179 & 0.4526 \\
$(-1.371)$ & $(-1.461)$ & $(-0.432)$ & $(10.642)$
\end{tabular}

Diagnostics

$\begin{array}{llll}\text { Number of Obs. } & 2558 & \text { Adj. R-squared } & 0.2725\end{array}$

Results of a linear regression model; $t$-Values in parentheses. 
Table A3: Re-employment Rates (Unemployment to Employment) - the Baseline Model

\begin{tabular}{llcl}
\hline \multirow{2}{*}{ Constant } & \multicolumn{3}{c}{ Core Values } \\
& 9.6803 & Female Deviation & -4.9120 \\
& $(12.627)$ & & $(-8.475)$ \\
& \multicolumn{3}{c}{ Demographics: Deviations from the Core } \\
& Unskilled & Medium-skilled & High-skilled \\
\hline Young (16-24) & -1.4197 & 5.2186 & 20.1845 \\
& $(-1.608)$ & $(6.483)$ & $(2.535)$ \\
Medium (25-49) & -6.1596 & - & 4.0589 \\
& $(-8.343)$ & & $(3.385)$ \\
Old (50-64) & -8.2781 & -9.3197 & -8.4551 \\
& $(-8.449)$ & $(-13.503)$ & $(-5.413)$
\end{tabular}

\section{Demographics: Female Deviations From Male Demographics}

\begin{tabular}{l|lll} 
& Unskilled & Medium-skilled & High-skilled \\
\hline Young (16-24) & 3.5296 & 1.6368 & -17.3660 \\
& $(2.883)$ & $(1.440)$ & $(-1.438)$ \\
Medium (25-49) & 4.8898 & - & -0.6028 \\
& $(4.467)$ & & $(-0.368)$ \\
Old (50-64) & 2.5457 & 3.5507 & 5.1692 \\
& $(1.934)$ & $(3.509)$ & $(1.205)$
\end{tabular}

Regimes

\begin{tabular}{llll} 
Regime 1: 1983-85 & Regime 2: 1986-88 & Regime 3: 1989-91 & Regime 4: 1992-94 \\
\hline-1.1316 & - & 0.8101 & -0.8677 \\
$(-2.476)$ & & $(1.597)$ & $(-1.852)$
\end{tabular}

Seasonal Factors

\begin{tabular}{llll} 
January & February & March & April \\
\hline 0.2152 & 4.2650 & 7.4741 & 4.3186 \\
$(0.262)$ & $(5.189)$ & $(8.995)$ & $(5.125)$ \\
May & June & July & August \\
\hline 1.6592 & - & 1.8006 & 2.9811 \\
$(1.945)$ & & $(2.146)$ & $(3.558)$ \\
September & October & November & December \\
\hline 3.5222 & 0.6314 & -1.7601 & 6.8699 \\
$(4.183)$ & $(0.750)$ & $(-2.106)$ & $(8.052)$
\end{tabular}

Diagnostics

$\begin{array}{llll}\text { Number of Obs. } & 2166 & \text { Adj. R-squared } & 0.3164\end{array}$

Results of a linear regression model; $t$-Values in parentheses. 